\title{
The Proportion of Cognitive Aspects of Question in Mathematics Textbook Based on Marzano's Taxonomy: An Indonesian Case in Implementing New Curriculum
}

\author{
Dhila Ardiani Rasyidi ${ }^{1}$, Widodo Winarso ${ }^{2 *}$ \\ 1, 2 Departement of Mathematics Education, IAIN Syekh Nurjati Cirebon
}

"Corresponding author: Perjuangan Stret, Sunyaragi, District. Kesambi, Cirebon City, West Java Province, Indonesia 45132. e-mail addresses: widodoiain@gmail.com

\section{a r t i c l e i n f o}

\author{
How to cite this article: \\ Rasidy, D. A, \& Winarso, W. (2020). The \\ Proportion of Cognitive Aspects of Question In \\ Mathematics Textbook Based on Marzano's \\ Taxonomy: An Indonesian Case in Implementing \\ New Curriculum. Eduma : Mathematics Education \\ Learning and Teaching, 9(2), 79 - 89. \\ doi:http://dx.doi.org/10.24235/eduma.v9i2.7374
}

Article history:

Received: 11 17, 2020

Accepted: 12 09, 2020

Published: 12, 2020

Copyright (C) 2020

EduMa: Mathematics Education Learning and Teaching under the Creative Commons Attribution 4.0 International License.

\section{a b s t r a c t}

THE PROPORTION OF COGNITIVE ASPECTS OF QUESTION IN MATHEMATICS TEXTBOOK BASED ON MARZANO'S TAXONOMY: AN INDONESIAN CASE IN IMPLEMENTING NEW CURRICULUM. Mathematical textbooks are one source of learning that has an important role in learning activities. But the existence of the government-issued mathematics textbook (BSE) which is currently widely used in class $\mathrm{X}$ high schools, still does not know the quality of its cognitive aspects. The purpose of this study was to find out the questions contained in class $\mathrm{X}$ high school mathematics textbooks had met the criteria of a good question according to the Marzano cognitive aspects. Qualitative descriptive research was used to analyze competency test questions in mathematics books. Data was collected through a question categorization checklist based on Marzano's cognitive aspects validated by experts. Guidelines for question analysis based on Marzano's taxonomy's cognitive aspects consisted of levels of cognitive retrieval, levels of cognitive understanding, levels of cognitive analysis, and levels of cognitive knowledge. The results showed that the percentage of question distribution for the recall rate was $17 \%$, at an understanding level of $14 \%, 30 \%$ analysis level, and $39 \%$ knowledge level; in other words, cognitive distribution in high school mathematics class $\mathrm{X}$ textbooks was still not ideal according to proportional allocation of aspects cognitive

Key word s :

Mathematical tests; Textbook; Cognitive; MarzanoTaksonomy 


\section{INTRODUCTION}

The curriculum in Indonesia has undergone a transition from the 2006 curriculum to the 2013 curriculum. The lessons applied in education units are too dense and overlapping, so the 2006 curriculum is refined in the 2013 curriculum (Ilma \& Pratama, 2015). The 2013 curriculum aims to encourage students to be better able to observe, ask, reason, and communicate (present) what they get or know after receiving learning material at school (Maba, 2017). Students will be more creative, innovative, and more productive so that later students can be successful in facing the various problems and challenges they find in learning activities. Learning activities in the 2013 Curriculum scheme are held to shape character, build knowledge, attitudes, and habits to improve student life quality (Prihantoro, 2015). Learning activities are expected to be able to empower all potential students to master the expected competencies. Students can develop attitudes and experiences according to their potential so that the teacher's role is no longer as a provider of knowledge but as a facilitator or helping students so that students can master the various competencies expected by the curriculum (Margalef \& Pareja Roblin, 2016).

Mathematics, which is one of the scientific fields, has an important role in schools and everyday life. The uses and benefits of studying mathematics can be felt in various ways. Apart from being a requirement for graduation at various levels, both primary school, junior high school, and high school in the Indonesian education system, mathematics can be applied in many ways such as trading or buying and selling activities that are always encountered every day (Cross, Woods, \& Schweingruber, 2009). For this reason, mathematics is one of the subjects that students must study in schools, including at the junior high school level.

Mathematics learning is a learning activity created by teachers to develop students' creative thinking skills (Vale \& Barbosa, 2015), and can increase the ability to build new knowledge (Saxe, 2015; Bodrova, \& Leong, 2015) as an effort to increase good mastery. On mathematics material (Bonnett, Yuill \& Carr, 2017). Learning mathematics in schools is characterized by the interaction between teachers and students, which involves developing thinking patterns and processing logic. The teacher creates such learning situations in an interactive learning environment. The success of a lesson is supported by the existence of various elements of learning. One important element in learning is teaching materials (Pratama \& Retnawati, 2018).

According to Collopy (2003), teaching materials are a part of teaching resources that can be interpreted as something that contains learning messages, both specific and general in nature, that can be used for learning purposes. One of the learning outcomes can be influenced by the availability of teaching materials that make it easier for individuals to study subject matter, resulting in better learning (Hong, 1996).

According to Jacobsen, Eggen, \& Kauchak (2002), there are several things teachers must do related to the availability of teaching materials, namely (1) providing various examples and representations of subject matter to students, (2) encouraging 
high levels of interaction in the learning process, (3) connecting the subject matter with the real world. The material that has been developed can be organized into teaching materials to make it easier for students to learn it.

The types of teaching materials are divided into several grouping criteria. Among them: (1) visual teaching materials are consisting of printed materials such as handouts, books, modules, student worksheets, brochures, pictures, and others; (2) audio teaching materials such as cassettes, radios, and audio compact disks; (3) audiovisual teaching materials such as video compact disks, films; (4) interactive multimedia teaching materials such as computer and web-based teaching materials (Hung, Chen \& Huang, 2017). Meanwhile, according to Smith (2016), the types of teaching materials based on the subject consist of two types, namely: (a) Teaching materials that are deliberately designed for learning, such as books, handout, worksheets, and modules; (b) Teaching materials that are not designed but can be used for learning, for example, clippings, newspapers, films, advertisements or news. One of the teaching materials that are often used in schools is textbooks or textbooks.

Textbooks are the primary reference book used by students and teachers in learning and teaching activities (Ronda \& Adler, 2017). The textbook in question is written work used by the teacher in the teaching and learning process (Hadar, 2017). Good textbooks are written in good and easy to understand language, presented in an attractive manner, accompanied by pictures and captions (Bellens, Van den Noortgate \& Van Damme, 2020). Students' content needs to be considered for its quality as one of the factors that influence success in learning. In subjects that require high cognitive level abilities, especially mathematics, it will be quite difficult for students to understand the material if they only rely on the teacher's explanation, therefore the need for textbooks as learning material in understanding mathematics.

Although the National Professional Certification Agency (BNSP) has conducted a feasibility assessment of these textbooks in textbooks in schools, one of them is the proportion of questions in textbooks that students can use in problem-solving reasoning is considered low (Mahmudi, 2019; Yang \& Sianturi, 2017). In line with the research conducted by Giani, Zulkardi \& Hiltrimartin (2015), on the cognitive level analysis of Mathematics textbook questions for grade VII based on Bloom's taxonomy by examining the questions in the BSE Mathematics Concept book and its application for grade VII SMP and MTs, the results of their research show The competency test questions in the equations and inequalities chapter are linear one variable at the cognitive level from remembering to analyzing. At the level of evaluating and making, no problems were found. The percentage of the number of questions piled up at the C3 level was 61.94\%. Another study conducted by Cahyono \& Adilah (2016), regarding the analysis of questions in the 2013 class VIII semester 1 mathematics curriculum book based on the TIMSS cognitive dimension, the result is the percentage of cognitive prayer contained in student books, the cognitive domain coverage has not matched the proportions tested on the dimensions cognitive in TIMSS was $11.63 \%$. From the various researches that have been done, it can be seen that the proportion of the questions is not evenly distributed so that it shows the weakness 
of the mathematics textbooks used in schools.

The 2013 curriculum revision in 2017 has produced the latest high school mathematics textbook published by the Ministry of Education and Culture (Kemendikbud), which is expected to meet the cognitive, psycho-motoric, and affective aspects of the characteristics of mathematics itself. Mathematics textbooks are effective if they are adapted to students' processing or cognitive abilities (Remillard, 1999). In mathematics, in particular, requires high-order thinking processes (Pratama \& Retnawati 2018). Because mathematics trains reasoning thinking and drawing conclusions, for example through investigation, exploration, experimentation, showing similarities, differences, consistency, and inter-consistency (Toheri, Winarso \& Haqq, 2019).

Cognitive can be defined as intelligence, thinking, and observing (Bjorklund \& Causey, 2017). Cognitive can also be defined as student behavior that produces knowledge or what is needed to acquire knowledge (Downs \& Stea, 2017). Thus, students who are able to coordinate various ways of thinking to solve problems by designing, remembering, and looking for alternatives to problem-solving are a measure of their cognitive development (Pike, 2000; Leonard, 2018).

According to Giani, Zulkardi \& Hiltrimartin (2015), argues that the ratio of good questions for the criteria for easy, medium, and difficult questions is 3: 4: 3 . Categories of easy questions are based on the level of cognitive ability to know and understand, and moderate category questions are at the ability to apply and analyze. Difficult level questions are at the level of ability to evaluate and create.
Based on this comparison, the percentage of questions for each cognitive level is formulated as follows, $30 \%$ for easy questions, $40 \%$ for medium category questions, and $30 \%$ for difficult category questions. Writing textbooks needs to analyze learning objectives by categorizing the elements or aspects of the learning objectives (Sitepu, 2012), one of which is by analyzing the items contained in the textbook based on the learning taxonomy.

According to Marzano's Taxonomy, the cognitive aspect can be used as a reference because it can be used as a measure of the ability of students in Indonesia, especially in mathematics. Kuswana (2012) explains that Marzano's taxonomy is a system that classifies outcome goals and a theoretical model of mental processes. The Marzano taxonomy can be used to make questions and help teachers measure students' abilities in applying certain levels according to student conditions. In fact, this taxonomy moves from a simpler way to a more complete process of both information or procedures, from less awareness to more awareness of more control over the knowledge process and how to structure or use it, from a lack of personal involvement or commitment to great trust centrally and a reflection of one's identity.

Fortuna (2018) states that the category of cognitive aspects in Marzano's taxonomy is more comprehensive because it interacts with "three initial knowledge," including information, mental procedures, and psychomotor procedures. Also, Marzano's taxonomy is descriptive so that it can explain a problem in more detail. This cognitive aspect of Marzano's taxonomy includes the process of knowledge procedures, recalling or doing without understanding (retrieval), processes of sequences or structures of knowledge, 
synthetics or steps and descriptions that are fundamental to basic understanding or comprehension, the process of accessing and examining knowledge about similarities and differences, diagnosing errors or consequent logic and predictable principles (analysis), the process of using knowledge from which problems can be addressed or solved, investigations can be planned, decisions and applications can be obtained (utilization).

In general, the purpose of this study is to determine the proportion of the cognitive distribution of questions based on the cognitive aspects of Marzano found in the class X BSE mathematics textbook (2017 revised edition Kurtilas).

\section{METHODS}

This type of research is a qualitative descriptive study, which examines the competency test questions in mathematics books (Lambert \& Lambert, 2012). The research object is the competency test questions in each chapter in the $\mathrm{X}$ grade mathematics BSE textbook (2017 revised edition Kurtilas) published by the Ministry of Education and Culture, consisting of 11 competency tests or 109 questions. The data was collected through a checklist categorization of questions based on Marzano's cognitive aspects, which were validated by experts. Guidelines for question analysis based on Marzano's taxonomy's cognitive aspects consist of cognitive retrieval level, cognitive comprehension level, cognitive analysis level, and cognitive knowledge level (Marzano \& Kendall, 2006; Irvine, 2017 ).

According to Irvine (2020), the criteria for Marzano's cognitive aspects at the retrieval level consist of a process of reasoning, remembering, reasoning, and implementation. Standards for cognitive aspects at the comprehension level consist of the process of reasoning taking and integrating. Criteria for cognitive aspects of analysis (analysis) consist of a reasoning process comparing, classifying, deductive reasoning, inductive reasoning, and error analysis. The criteria for the cognitive aspect of knowledge (knowledge) consist of the reasoning process of investigating, experimenting, problem-solving, and making decisions.

Competency test questions were grouped first. After being grouped, the questions were categorized by means of a checklist. In the checklist process, the researcher first determines the questions that are included in each cognitive level. The next stage is then validated by expert validators. The final result has obtained the percentage at each cognitive level.

\section{RESULT AND DISCUSSION}

Textbooks are used as a means of learning and learning carried out by teachers and students in schools. According to Wuryani \& Yamtinah (2018), textbooks are a means to support teaching and learning activities. Also, textbooks are also a supporting book for the government's student learning (Murdaningsih \& Murtiyasa, 2016). In this case, the textbook referred to, one of which is the Mathematics Electronic Standard Book (BSE) of Class X textbook, which is currently widely used in schools. With the textbook, it is expected that the learning process can run conducive to the expected learning objectives. However, there are still weaknesses in textbooks in schools, even though BNSP has conducted a feasibility assessment of the textbooks (Giani, Zulkardi, \& Hiltrimartin, 2015; Agustina, 2018).

The mathematics textbook (BSE) of Class $\mathrm{X}$ is one of the textbooks that is often used 
in schools; this textbook has undergone several improvements from year to year. The last issue of the 2017 revised edition of the class X Kurtilas mathematics textbook in 2017. The cognitive quality of the book is not yet known. The researcher is interested in analyzing the X class X BSE mathematics textbook from a cognitive aspect. This right aims to determine the quality of textbooks based on the cognitive development of class $\mathrm{X}$ students. The method is to analyze the questions presented in each competency test.
The researcher conducted an analysis of 11 competency tests or 109 items based on Marzano's taxonomy's cognitive aspects. The cognitive aspect of Marzano consists of 4 cognitive levels. The four groups consist of; calling or remembering, comprehension, analysis, and knowledge. Based on the analysis of the $\mathrm{X}$ BSE mathematics textbook, which consists of 11 competency tests with a total of 109 questions. Cognitive level data were obtained based on the cognitive aspects of Marzano's taxonomy as follows.

Table 1. Distribution of Test on Marzano's Cognitive Aspects

\begin{tabular}{cccccc}
\hline $\begin{array}{c}\text { Chapter / } \\
\text { Competency } \\
\text { Test }\end{array}$ & Retrieval & Comprehension) & Analysis & Knowledge & $\begin{array}{c}\text { Number of } \\
\text { questions- } \\
\text { competency } \\
\text { test }\end{array}$ \\
\hline $1 / 1.1$ & 1 & 1 & 2 & 2 & 6 \\
$1 / 1.2$ & 1 & 4 & 2 & 3 & 10 \\
$2 / 2.1$ & 3 & 0 & 4 & 3 & 10 \\
$2 / 2.2$ & 0 & 0 & 7 & 3 & 10 \\
$3 / 3.1$ & 0 & 0 & 3 & 7 & 10 \\
$3 / 3.2$ & 0 & 0 & 4 & 8 & 12 \\
$4 / 4.1$ & 2 & 3 & 3 & 2 & 10 \\
$4 / 4.2$ & 2 & 3 & 1 & 5 & 11 \\
$4 / 4.3$ & 2 & 2 & 3 & 3 & 10 \\
$4 / 4.4$ & 4 & 1 & 2 & 3 & 10 \\
$4 / 4.5$ & 4 & 1 & 2 & 3 & 10 \\
Total & 19 & 15 & 33 & 42 & 109 \\
\hline
\end{tabular}

The percentage calculation for each cognitive level is obtained in the following way:

1) Retrieval

$$
\frac{19}{109} \times 100 \%=17 \%
$$

2) Comprehension

$$
\frac{15}{109} \times 100 \%=14 \%
$$

3) Analysis

$$
\frac{33}{109} \times 100 \%=30 \%
$$

4) Knowladge)

$$
\frac{42}{109} \times 100 \%=39 \%
$$

Based on Table 1, the proportion of questions obtained in this study has a different cognitive distribution. Of the 109 question items, 19 items are included in the retrieval level. The percentage is $17 \%$, 15 items are included in the comprehension level, or the percentage is $14 \%$, then 33 items are included in the level. The percentage analysis was $30 \%$, and 42 items were included in the knowledge level (knowledge), or the percentage was $39 \%$. These results can be clarified in the following figure 1. 


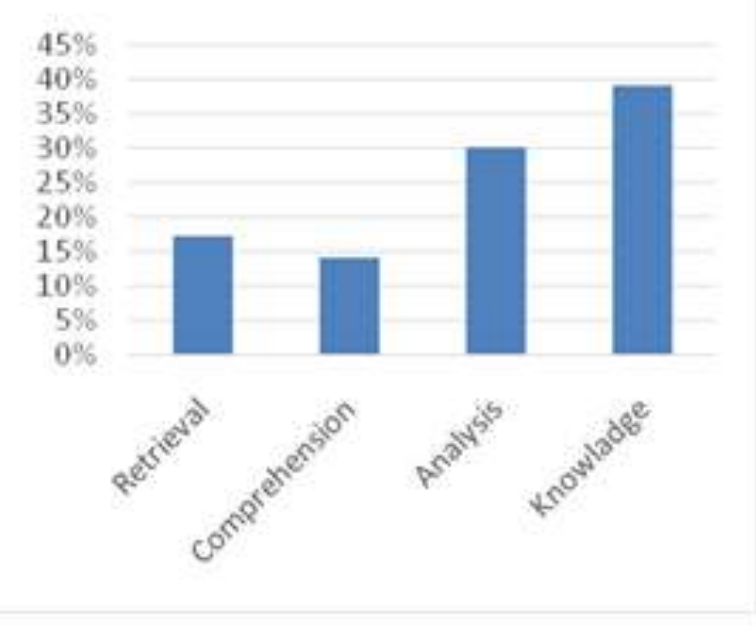

Figur1. Cognitive Levels Based on Marzano's Cognitive Aspects

In determining the criteria for a good question in a mathematics textbook, it is necessary to compare questions used as a reference or guideline so that the quality of a textbook is known whether it is proportional or still needs improvement. The ratio of good questions for the criteria for easy, medium, and difficult questions is 3: $4: 3$, or the percentage is $30 \%$ for easy category questions, $40 \%$ for medium category questions, and 30\% for difficult category questions. Category questions are easy to develop based on the cognitive level of knowledge and understanding, category questions are being developed from the level of ability to apply and analyze, and categorical questions are difficult to develop from the level of ability to draw conclusions, evaluate and create (Giani, Zulkardi \& Hiltrimartin, 2015;). According to Wulandari (2014) that the cognitive level of calling or remembering (retrieval) consists of the reasoning process of recalling, experiencing, and implementing or interpreted as the ability to remember. The cognitive level of comprehension (comprehension) consists of reasoning taking and integrating or interpreting comprehension skills. Furthermore, the cognitive level of analysis (analysis) consists of the reasoning process of comparing, classifying, deductive reasoning, inductive reasoning, and error analysis. The cognitive level of knowledge (knowledge) consists of the process of reasoning investigations, problem-solving, experimenting, and making decisions or is interpreted as the ability to draw conclusions and evaluate

Based on this information, it was found that the question criteria according to Marzano's taxonomy were $15 \%$ for questions included in the retrieval level, $15 \%$ for questions included in the comprehension level, $40 \%$ for questions included in the cognitive analysis level ( analysis) and 30\% for questions included in the cognitive level of knowledge (knowledge). Based on table IV. This percentage shows that the composition of the questions is not good because the proportion of questions in this mathematics textbook does not meet the criteria for a good proportion of questions according to the cognitive aspects of Marzano's taxonomy, namely by referring to the comparison of the question criteria in order of 15\%: 15\%: 40\%: $30 \%$. Comparing the question criteria obtained in the X grade mathematics BSE textbook (2017 revised edition Kurtilas) is presented in the following table.

Table 2. Comparison of Question Criteria

\begin{tabular}{|c|c|c|c|c|}
\hline \multirow{3}{*}{$\begin{array}{l}\text { Propor } \\
\text { tion } \\
\text { Test } \\
\text { Teori } \\
\text { Sujan } \\
\text { a } \\
(2004)\end{array}$} & \multicolumn{4}{|c|}{ Category } \\
\hline & & Easy & $\begin{array}{c}\text { Mode } \\
\text { rate }\end{array}$ & Hard \\
\hline & & $30 \%$ & $40 \%$ & $30 \%$ \\
\hline \multirow{2}{*}{$\begin{array}{l}\text { Deriva } \\
\text { tion of } \\
\text { the } \\
\text { Sujan } \\
\text { a } \\
\text { theory } \\
\text { to } \\
\text { Marza } \\
\text { no }\end{array}$} & $\begin{array}{c}\text { Retrie } \\
\text { val }\end{array}$ & $\begin{array}{c}\text { Comprehe } \\
\text { nsion }\end{array}$ & $\begin{array}{c}\text { Analy } \\
\text { sis }\end{array}$ & $\begin{array}{c}\text { Knowl } \\
\text { edge }\end{array}$ \\
\hline & $15 \%$ & $15 \%$ & $40 \%$ & $30 \%$ \\
\hline $\begin{array}{l}\text { Resear } \\
\text { ch } \\
\text { result }\end{array}$ & $17 \%$ & $14 \%$ & $30 \%$ & $39 \%$ \\
\hline
\end{tabular}

Based on this information, the proportion of research results on mathematics textbook questions at the cognitive level of calling or remembering (retrieval) ideally 
contains a percentage of questions of $15 \%$, while the results of this study are questions that include a level of understanding that exceeds the standard questions, namely $17 \%$, the level of cognitive comprehension. Ideally, it contains a percentage of questions as large as $15 \%$, whereas, in the results of this study, only the proportion of questions is $14 \%$ or still below the standard, then for questions that are included in the analysis level. Ideally it contains a percentage of $40 \%$. In comparison, this study's results only get a proportion of $30 \%$ of the questions, which means that the proportion of questions is still far below the standard. The level of knowledge (knowledge) should ideally have a proportion of questions of $30 \%$. In contrast, this study's results show that the proportion of questions is $39 \%$, which means that these questions' ratio exceeds the criteria for good standard questions.

According to Piaget's theory in Upton (2012), high school class X students are included in cognitive development's formal operational stage (11 years and over). At this stage, the child can do reasoning using abstract things and using logic. In certain subjects, especially mathematics, class $\mathrm{X}$ high school students have arrived at a higher cognitive level. As stated by Susanti, Trapsilasiwi \& Kurniati (2015), states that mathematics textbooks will be effective if they are adjusted to the processing or cognitive abilities of the readers, so it is necessary to classify students' cognitive levels in working on questions in stages, from the easy to the most difficult.

\section{CONCLUSION AND IMPLICATION}

\section{a. Conclusion}

The results of the analysis of the questions in the $\mathrm{X}$ grade mathematics BSE book (Kurtilas 2017 revised edition) concluded that the cognitive distribution according to Marzano's taxonomy on the revised edition 2017 BSE Mathematics competency test questions, totaling 109 questions, got the distribution of questions, namely the summons retrieval as many as 19 items or the percentage is $17 \%$, comprehension is 15 items or the percentage is $14 \%$, analysis is 33 items or the percentage is $30 \%$, and knowledge (knowledge) is 42 items questions or the percentage is $39 \%$.

The proportion of questions contained in the BSE SMA Mathematics class x (2017 revised edition Kurtilas is not proportional according to the cognitive aspects of Marzano's taxonomy as ideally, it should meet the right question criteria, namely $15 \%$ for the level of summons (retrieval), $15 \%$ for the level of cognitive comprehension, $40 \%$ for the cognitive level of analysis (analysis) and 30\% for the cognitive level of knowledge (knowledge), so there is still a need for improvement in the making of questions adjusted to these criteria.

\section{b. Implication}

Research on the analysis of this book is preliminary because it only looks at the cognitive realm. In addition to cognitive analysis, question analysis on other cognitive aspects of the $\mathrm{X}$ class curriculum BSE mathematics textbook's questions can be carried out in other research fields. This was done to find out more about the quality of the questions in the X Kurtilas class X mathematics BSE book. Improvements to the content of textbooks, both teacher and student books must be carried out continuously to compile quality mathematics textbooks, which can be used nationally according to the 2013 curriculum formulation.

\section{REFERENCES}

Agustina, N. M. K. (2018). Analisis Soal Dalam Buku Teks Matematika SMP Kelas VII Berdasarkan Pada Taksonomi Bloom Revisi (Doctoral dissertation, UIN Sunan Ampel 
Surabaya). Retrieved from http://digilib.uinsby.ac.id/27435/

Bellens, K., Van den Noortgate, W., \& Van Damme, J. (2020). The Informed Choice: Mathematics Textbook Assessment in Light of Educational Freedom, Effectiveness, and Improvement in Primary Education. School Effectiveness and School Improvement, 31(2), 192211.

https://doi.org/10.1080/09243453.20 19.1642215

Bjorklund, D. F., \& Causey, K. B. (2017). Children's Thinking: Cognitive Development and Individual Differences. Sage Publications.

Bodrova, E., \& Leong, D. J. (2015). Vygotskian and Post-Vygotskian Views on Children's Play. American Journal of Play, 7(3), 371-388. https://doi.org/10.4324/9781315641 $\underline{560-5}$

Bonnett, V. M., Yuill, N., \& Carr, A. (2017). Mathematics, Mastery and Metacognition: How Adding a Creative Approach Can Support Children in Maths. Educational and Child Psychology, 34(1), 83-93.

Cahyono, B., \& Adilah, N. (2016). Analisis Soal Dalam Buku Siswa Matematika Kurikulum 2013 Kelas VIII Semester I Berdasarkan Dimensi Kognitif Dari TIMSS. JRPM (Jurnal Review Pembelajaran Matematika), 1(1), 86-98.

https://doi.org/10.15642/jrpm.2016. 1.1.86-98

Collopy, R. (2003). Curriculum Materials As a Professional Development Tool: How a Mathematics Textbook Affected Two Teachers' Learning. The elementary school journal, 103(3), 287-311. https://doi.org/10.1086/499727

Cross, C. T., Woods, T. A., \& Schweingruber, H. E. (2009). Mathematics Learning in Early Childhood: Paths Toward Excellence and Equity. National
Academies

Press. https://doi.org/10.4324/9780203883 785-1

Downs, R. M., \& Stea, D. (Eds.). (2017). Ima ge and Environment: Cognitive Mapping and Spatial Behavior. Transaction Publishers. https://doi.org/10.2307/213853

Giani, G., Zulkardi, Z., \& Hiltrimartin, C. (2015). Analisis Tingkat Kognitif Soal-Soal Buku Teks Matematika Kelas VII Berdasarkan Taksonomi Bloom. Jurnal Pendidikan Matematika, 9(2), 78-98. https://dx.doi.org/10.22342/jpm.9.2. 2125.78\%20-\%2098

Hadar, L. L. (2017). Opportunities to Learn: Mathematics Textbooks and Students' Achievements. Studies in Educational Evaluation, 55, 153166.

https://doi.org/10.1016/j.stueduc.20 17.10 .002

Hong, H. (1996). Effects of Mathematics Learning Through Children's Literature on Math Achievement and Dispositional Outcomes. Early childhood research quarterly, 11(4), 477-494.

https://doi.org/10.1016/s08852006(96)90018-6

Hung, Y. H., Chen, C. H., \& Huang, S. W. (2017). Applying Augmented Reality to Enhance Learning: A Study of Different Teaching Materials. Journal of Computer Assisted Learning, 33(3), 252-266. https://doi.org/10.1111/jcal.12173

Ilma, Z., \& Pratama, R. K. (2015). Transformation in Indonesian Language Curriculum: Pros and Cons between KTSP 2006 and Curriculum 2013 in Indonesia. In Proceedings of Internationl Conference on Trends in Economics. Humanities and Management (pp. 146-148).

https://doi.org/10.15242/icehm.ed03 15007

Irvine, J. (2017). A Comparison of Revised Bloom and Marzano's New Taxonomy of Learning. Research in 
Higher Education Journal, 33, 1-16. Retrieved from https://eric.ed.gov/?id=EJ1161486

Irvine, J. (2020). Marzano's New Taxonomy as a Framework for Investigating Student Affect. Journal of Instructional Pedagogies, 24, 1-31. Retrieved from https://eric.ed.gov/?id=EJ1263740

Jacobsen, D. A., Eggen, P. D., \& Kauchak, D. P. (2002). Methods for Teaching: Promoting Student Learning. Prentice Hall.

Lambert, V. A., \& Lambert, C. E. (2012). Qualitative Descriptive Research: An Acceptable Design. Pacific Rim International Journal of Nursing Research, 16(4), 255-256.

Leonard, J. (2018). Culturally Specific Pedagogy in The Mathematics Classroom: Strategies for Teachers and Students. Routledge.

Maba, W. (2017). Teacher's Perception on the Implementation of the Assessment Process in 2013 Curriculum. International journal of social sciences and humanities, 1(2), 1-9. https://doi.org/10.29332/ijssh.v1n2. $\underline{26}$

Mahmudi, A. (2019). Analysis of The Junior High School Mathematics Textbook in Indonesia Based on The Content Of Higher Order Thinking Skills. In Journal of Physics: Conference Series (Vol. 1387, No. 1, p. 012069). IOP Publishing. https://doi.org/10.1088/17426596/1387/1/012069

Margalef, L., \& Pareja Roblin, N. (2016). Unpacking The Roles of The Facilitator in Higher Education Professional Learning Communities. Educational Research and Evaluation, 22(3-4), 155-172.

https://doi.org/10.1080/13803611.20 16.1247722

Marzano, R. J., \& Kendall, J. S. (2006). The New Taxonomy of Educational Objectives. Corwin Press.
Murdaningsih, S., \& Murtiyasa, B. (2016). An Analysis on Eight Grade Mathematics Textbook of New Indonesian Curriculum (K-13) Based on Pisa's Framework. JRAMathEdu (Journal of Research and Advances in Mathematics Education), 1(1), 14-27.

https://doi.org/10.23917/jramathed u.v1i1.1780

Ojose, B. (2008). Applying Piaget's Theory of Cognitive Development to Mathematics Instruction. The mathematics educator, 18(1), 26-30.

Pike, G. R. (2000). The Influence of Fraternity or Sorority Membership on Students' College Experiences and Cognitive Development. Research in Higher Education, 41(1), 117-139. https://doi.org/10.1023/a:100704651 $\underline{3949}$

Pratama, G. S., \& Retnawati, H. (2018). Urgency of Higher Order Thinking Skills (HOTS) Content Analysis in Mathematics Textbook. In Journal of Physics: Conference Series (Vol. 1097, No. 1, p. 012147). IOP Publishing.

https://doi.org/10.1088/1742 6596/1097/1/012147

Prihantoro, C. R. (2015). The Perspective of Curriculum in Indonesia on Environmental

Education. International Journal of Research Studies in Education, 4(1), 77-83.

https://doi.org/10.5861/ijrse.2014.91 5 77-83.

Remillard, J. T. (1999). Curriculum Materials in Mathematics Education Reform: A Framework for Examining Teachers' Curriculum Development.

Curriculum Inquiry, 29(3), 315-342. https://doi.org/10.1111/03626784.00130

Ronda, E., \& Adler, J. (2017). Mining Mathematics in Textbook Lessons. International Journal of 
Science and Mathematics

Education, 15(6), 1097-1114.

https://doi.org/10.1007/s10763-016-

9738-6

Saxe, G. B. (2015). Culture and Cognitive

Development: Studies in

Mathematical Understanding.

Psychology Press.

https://doi.org/10.4324/9781315788

$\underline{968}$

Setyowati, P. A., \& Sutrisno, H. (2020). An Analysis of Representation Level and Cognitive Level in Curriculum2013 Chemistry Textbook. In Journal of Physics: Conference Series (Vol. 1440, No. 1, p. 012006). IOP Publishing. https://doi.org/10.1088/17426596/1440/1/012006

Smith, K. J. (2016). Nature of Mathematics. Cengage Learning.

Susanti, N. Y., Trapsilasiwi, D., \& Kurniati, D. (2015). Analisis Tingkat Kognitif Uji Kompetensi pada Buku Sekolah Elektronik (BSE) Matematika SMP/MTs Kelas VII Kurikulum 2013 Berdasarkan Taksonomi Bloom. Kreano, Jurnal Matematika Kreatif-Inovatif, 6(1), 67-75.

https://doi.org/10.15294/kreano.v6i $\underline{1.4509}$

Toheri, Winarso. W., \& Haqq, A. A. (2019). Three Parts of 21 Century Skills: Creative, Critical, and Communication Mathematics through Academic-constructive
Controversy. Universal Journal of Educational Research, 7(11), 23142329.

https://doi.org/10.13189/ujer.2019.0 71109

Upton, P. (2012). Belajar Cepat Psikologi: Psikologi Perkembangan. Jakarta: Erlangga.

Vale, I., \& Barbosa, A. (2015). Mathematics Creativity In Elementary Teacher Training. Journal of the european teacher education network, 10, 101109.

Wulandari, Y. O. (2014). Proses Berpikir Aljabar Siswa Berdasarkan Taksonomi Marzano (Doctoral dissertation, Universitas Negeri Malang).

Wuryani, M. T., \& Yamtinah, S. (2018). Textbooks Thematic Based Character Education on Thematic Learning Primary School: An Influence. International Journal of Educational Methodology, 4(2), 7581.

https://doi.org/10.17051/ilkonline.2 $\underline{018.413768}$

Yang, D. C., \& Sianturi, I. A. (2017). An Analysis of Singaporean Versus Indonesian Textbooks Based on Trigonometry Content. Eurasia Journal of Mathematics, Science and Technology Education, 13(7), 3829-3848.

https://doi.org/10.12973/eurasia.201 7.00760a 